\title{
Efektivitas Larutan Bawang Putih dalam Pengendalian Larva Aedes Agypti
}

\section{The Effectiveness of Solution Garlic in Aedes Aegypti Larva Control}

\author{
Muhammad Ikhtiar ${ }^{1}$, Sitti Patimah ${ }^{1 *}$, Nur Fadhilah Rasyidi ${ }^{1}$, Yusriani $^{1}$, Hidayat ${ }^{2}$ \\ ${ }^{1}$ Fakultas Kesehatan Masyarakat Universitas Muslim Indonesia \\ ${ }^{2}$ Jurusan Kesehatan Lingkungan, Politeknik Kesehatan Makassar \\ (*imhasudirman@gmail.com)
}

\begin{abstract}
ABSTRAK
Upaya pengendalian Demam Berdarah Dengue menggunakan insektisida menimbulkan risiko resistensi pada nyamuk dan tidak ramah lingkungan, sehingga diperlukan metode alternatif pengendalian larva aedes agypti berbasis bahan alam. Penelitian ini bertujuan membandingkan efektifitas bubuk abate dan larutan bawang putih dalam membunuh larva nyamuk Aedes aegypti dengan berbagai macam konsentrasi, menggunakan design eksperimen murni dengan pendekatan Rancangan Acak Lengkap. Sampel penelitian adalah larva nyamuk Aedes aegypti stadium III dan IV dengan jumlah sampel sebanyak 25 ekor larva yang dimasukkan ke dalam bubuk abate dan larutan bawang putih dengan konsentrasi $20 \mathrm{mg} / 100 \mathrm{ml}, 40 \mathrm{mg} / 100 \mathrm{ml}, 60 \mathrm{mg} / 100 \mathrm{ml}, 80 \mathrm{mg} / 100 \mathrm{ml} \mathrm{dan}$ $100 \mathrm{mg} / 100 \mathrm{ml}$. Observasi kematian larva dilakukan pada waktu 20 menit, 40 menit, 60 menit dan 24 jam. Kecepatan reaksi bubuk abate lebih cepat (40 menit) dibandingkan larutan bawang putih (24 jam). Jumlah kematian larva berbanding lurus dengan konsentrasi bubuk abate maupun bawang putih, kematian larva tertinggi pada waktu 24 jam. Berdasarkan uji Mann Whitney diperoleh tidak ada perbedaan yang signifikan antara bubuk abate dan larutan bawang putih dalam pengendalian larva aedes agypti pada konsentrasi $100 \mathrm{mg}$ dalam waktu pengamatan 24 jam $(\mathrm{p}=1.000)$. Disimpulkan bahwa bubuk abate dan larutan bawang putih pada konsentrasi 100 mg mempunyai efektifitas yang sama dalam pengendalian larva aedes agypti dalam waktu 24 jam.
\end{abstract}

Kata kunci : Bubuk abate, bawang putih, larva aedes agypti

\section{ABSTRACT}

Efforts to control Dengue Hemorrhagic Fever using insecticides pose a risk of resistance to mosquitoes and are not environmentally friendly, so an alternative method of controlling Aedes agypti larvae based on natural materials is needed. This study aims to compare the effectiveness of abate powder and garlic solution in controlling Aedes aegypti larvae with various concentrations, by using true experimental design with a completely randomized design. The samples was Aedes aegypti larvae stage III and IV with total sample of 25 larvae which put into abate powder and garlic solution with a concentration of $20 \mathrm{mg} / 100 \mathrm{ml}, 40 \mathrm{mg} / 100 \mathrm{ml}, 60 \mathrm{mg} / 100 \mathrm{ml}$, $80 \mathrm{mg} / 100 \mathrm{ml}$, and $100 \mathrm{mg} / 100 \mathrm{ml}$. Abate powder reaction speed is faster (40 minutes) than garlic solution (24 hours). The number of straight larvae deaths with concentrations of abate and garlic powder, the highest mortality of larvae at 24 hours. Based on the Mann Whitney test, there was no significant difference between abate powder and garlic solution in controlling Aedes agypti larvae at a concentration of $100 \mathrm{mg}$ in 24 hours observation $(p=$ 1,000). Therefore, abate powder and garlic solution at a concentration of $100 \mathrm{mg}$ had the same effectiveness in controlling larvae of Aedes agypti within 24 hours.

Keywords : Abate powder, garlic, aedes aegypti larvae 


\section{PENDAHULUAN}

Nyamuk tidak hanya mengancam kesehatan manusia tetapi juga berdampak buruk terhadap kehidupan karena mereka bertindak sebagai vektor bagi banyak penyakit mengerikan. Diantara spesies nyamuk, Aedes aegypti memainkan peran vektor kunci untuk menularkan penyakit virus seperti Demam Berdarah Dengue (DBD). ${ }^{1}$ Demam Berdarah Dengue (DBD) dapat mengancam jiwa manusia dan dianggap sebagai masalah kesehatan masyarakat internasional utama saat ini. Nyamuk betina dari sebagian besar spesies Aedes aegypti bertanggung jawab atas penularan virus dengue, yang menyerang lebih dari 100 negara di seluruh dunia. Penyakit ini tersebar luas di seluruh daerah tropis dan non tropis dengan variasi risiko lokal yang dipengaruhi oleh iklim (curah hujan), perubahan suhu, globalisasi dan urbanisasi cepat yang tidak terencana, serta status sosial ekonomi. Hingga 400 juta orang terinfeksi setiap tahun. Demam berdarah berdampak pada aspek sosial dan ekonomi akibat rawat inap dan kematian di antara populasi menjadi penyebab perhatian dunia. $^{2}$

Penyakit Demam Berdarah Dengue (DBD) merupakan salah satu masalah kesehatan masyarakat di Indonesia, ditandai dengan jumlah penderita semakin meningkat dan penyebarannya semakin luas. Jumlah kasus DBD mengalami penurunan dari 204.171 (tahun 2016) menjadi 68.407 kasus (tahun 2017), dikuti penurunan insiden rate dari 78.85 per 100.000 penduduk (tahun 2016) menjadi 26.12 per 100.000 penduduk, kemudian diikuti penurunan jumlah kematian sebanyak 3 kali lipat yaitu dari 1598 orang menjadi 493 orang. Sebaliknya, angka bebas jentik secara nasional belum mencapai target program $(>95 \%)$, bahkan ada kecenderungan penurunan pencapaian target dari 67.6\% (tahun 2016) menjadi 46.7\% (tahun 2017). Di propinsi Sulawesi Selatan insiden rate DBD sebesar 19.96 per 100.000 penduduk dengan angka CFR (Case Fatality Rate) sebesar 0.63 dibawah dari angka nasional $(0.72) .{ }^{3} \mathrm{Na}-$ mun tetap perlu dilakukan upaya pengendalian untuk membasmi larva Aedes aegypti yang akan menjadi nyamuk sebagai pembawa virus dengue, akibat perubahan iklim global dan globalisasi. Pengendalian secara kimiawi menggunakan bubuk abate sebagai salah satu upaya pengendalian jentik nyamuk masih popular saat ini selain dari fogging. Namun, strategi tersebut tidak ramah lingkungan, menimbulkan efek yang tidak diinginkan pada organisme non-target, serta dapat menimbulkan resistensi pada nyamuk terhadap berbagai insektisida sintetik. Oleh karena itu, untuk mengatasi keadaan ini, lebih banyak penekanan harus diberikan pada strategi pengendalian biologi menggunakan metabolit sekunder dari tumbuhan, karena kaya komponen bioaktif dengan aktivitas larvasida. ${ }^{1}$

Pengendalian larva secara alami berbasis tanaman atau botani menjadi sebuah kebutuhan saat ini, karena menawarkan penolakan (repellency) atau kemampuan membunuh nyamuk yang tinggi serta keamanan konsumen yang baik ${ }^{4}$, dan mudah terdegradasi dan kurang toksik pada lingkungan ${ }^{5}$ karena tidak meninggalkan residu di udara, air dan tanah serta mempunyai tingkat keamanan yang lebih tinggi. ${ }^{6}$ Selama ini, bawang putih (Allium sativum) dikenal hanya sebagai bumbu makanan, namun ternyata dapat berperan sebagai media untuk pengendalian larva Aedes aegypti karena mengandung berbgai komponen biokatif (Allicin, sulfur amonia Acid Allin, garlic oil dan flavonoid) yang telah terbukti memiliki efek larvasida terhadap kematian larva Aedes aegypti, sehingga dapat digunakan sebagai insektisida dengan sifat anti nyamuk dan biosidal. Allicin mengalami perubahan menjadi Diallyl Sulphide. Senyawa Allicin dan Diallyl Sulphide bersifat larvasida atau insektisida. ${ }^{7}$ Sebagaimana dibuktikan dari beberapa studi sebelumnya bahwa Allyl disulfide memiliki aktivitas ovicidal dan larvicida yang kuat, dan berkontribusi pada toksisitas nyamuk, ${ }^{8}$ dan jika dibandingkan dengan ekstrak tumbuhan lain, Allium sativum lebih efektif dalam aktivitas larvikidal terhadap Aedes aegypty. ${ }^{5}$ Akan tetapi, belum ada satu pun studi yang membandingkan pemberian bawang putih (Allium sativum) dengan bubuk abate terhadap pengendalian larva Aedes aegypti. Olehnya itu, penelitian ini bertujuan untuk membandingkan efektifikas larutan bawang putih dengan bubuk abate untuk membunuh larva nyamuk Aedes aegypti dengan berbagai tingkat konsentrasi.

\section{BAHAN DAN METODE}

Penelitian ini merupakan eksperimen laboratorium dengan rancangan acak lengkap, 
menggunakan post test only with control group design, terdiri atas dua kelompok yaitu kelompok intervensi (larutan bawang putih) dan kelompok kontrol positif (larutan bubuk abate). Penelitian ini dilaksanakan di Laboratorium Kesehatan Masyarakat, Fakultas Kesehatan Masyarakat Universitas Muslim Indonesia, pada tahun 2017. Populasi dalam penelitian ini adalah 4800 larva Aedes aegypti. Jumlah sampel yang diperlukan adalah 125 ekor larva instar III dan IV untuk 5 konsentrasi yaitu $20 \mathrm{mg} / 100 \mathrm{ml}, 40 \mathrm{mg} / 100 \mathrm{ml}$, $60 \mathrm{mg} / 100 \mathrm{ml}, 80 \mathrm{mg} / 100 \mathrm{ml}, 100 \mathrm{mg} / 100 \mathrm{ml}$. Umur larva merupakan faktor penggangu terhadap hasil penelitian intervensi, oleh karena itu digunakan instar III dan IV yang mengindikasikan bahwa larva Aedes aegypti sudah memiliki morfologi yang sempurna. Setiap konsentrasi dimasukan 25 ekor larva Aedes Aegypti. Sampel diambil menggunakan saringan ikan, dengan menggunakan kaca pembesar lalu diamati dan sortir, mana yang termasuk larva Aedes aegypti instar III dan IV dengan ciri-ciri Instar III (ada abdomen tetapi di kepalanya belum terdapat bulu-bulu dan antenna, sedangkan instar IV semuanya sudah nampak (ada abdomen, antena, dan thoraks, kemudian dimasukan ke dalam toples (wadah sampel) yang sudah berisi air. Toples yang sudah berisi sampel ditutup dan diberi lubang udara.

Alat yang digunakan terdiri atas: beaker glass, gelas ukur, pipet volum, toples, blender, kain kasa, karet, batang pengaduk, obyek dan deck glass, saringan ikan, kaca pembesar, dan mikroskop. Bahan yang digunakan meliputi: larva nyamuk Aedes aegypti, bawang putih $200 \mathrm{~g}$, bubuk Abate, dan Aquadest. Larutan bawang putih dibuat dengan cara mengupas bawang putih $200 \mathrm{~g}$, kemudian ditambahkan 10 liter air kemudian diblender hingga halus, larutan bawang putih didiamkan selama 15 menit kemudian disaring untuk memisahkan dari ampasnya. Pembuatan larutan abate dilakukan dengan menimbang abate sebanyak $1 \mathrm{~g}$, lalu dimasukkan ke dalam 10 liter air, kemudian diaduk sampai abate dan air menyatu. Selanjutnya dilakukan intervensi dengan memasukan aquadest sebanyak $100 \mathrm{ml}$ ke dalam masing-masing beaker glass, kemudian memasukan larutan bawang putih sesuai dengan konsentrasi $20 \mathrm{mg} / 100 \mathrm{~mL}$, $40 \mathrm{mg} / 100 \mathrm{~mL}, 60 \mathrm{mg} / 100 \mathrm{~mL}, 80 \mathrm{mg} / 100 \mathrm{~mL}$, dan $100 \mathrm{mg} / 100 \mathrm{~mL}$, dilanjutkan pengukuran suhu dan
$\mathrm{pH}$ masing-masing media uji dan dicatat hasil pengukuran, selanjutnya dimasukkan 25 ekor larva ke dalam masing-masing wadah uji, kemudian menghitung jumlah larva yang mati di menit ke 20, menit ke 40, menit ke 60, dan 24 jam, serta mengambilnya dengan menggunakan pipet larva, dan dicatat hasil pengamatan. Pengulangan dilakukan sebanyak 4 kali. Demikian dengan perlakuan pada larutan bubuk abate. Setelah data terkumpul dilakukan analisis data secara univariate (frekuensi dan presentase) dan bivariate menggunakan uji statistik (Uji Mann Whitney) dengan tingkat kemaknaan $95 \%(\alpha=5 \%)$.

\section{HASIL}

Sebelum dilakukan intervensi pada larva nyamuk Aedes aegpyti, terlebih dahulu dilakukan studi pendahuluan untuk mengukur suhu media uji dan $\mathrm{pH}$ air pada fase awal dan akhir, untuk mengontrol pengaruh kedua variabel tersebut dalam kematian larva nyamuk Aedes aegpyti. Hasilnya menunjukkan bahwa kondisi suhu awal dan akhir pada penggunaan media bubuk abate dan bawang putih diperoleh suhu masing-masing sebesar $25^{\circ} \mathrm{C}$ dengan berbagai konsentrasi $(20$ $\mathrm{mg} / \mathrm{ml}, 40 \mathrm{mg} / \mathrm{ml}, 60 \mathrm{mg} / \mathrm{ml}, 80 \mathrm{mg} / \mathrm{ml}, 100 \mathrm{mg} /$ $\mathrm{ml})$ yang mengindikasikan bahwa suhu tersebut merupakan kondisi yang baik bagi larva nyamuk Aedes aegypti untuk hidup dengan baik, demikian pula dengan $\mathrm{pH}$ air yang digunakan dalam pelarutan bubuk abate dan bawang putih diperoleh hasil pengukuran $\mathrm{pH}$ awal dan akhir sebesar 6 yang mengindikasikan bahwa pH 6 tersebut merupakan kondisi keasaman yang layak bagi larva nyamuk Aedes aegpyti untuk hidup dengan baik. Hal ini berarti bahwa kematian larva nyamuk Aedes aegypti bukan dikarenakan pengaruh suhu dan $\mathrm{pH}$.

Tabel 1 menunjukkan bahwa tidak terdapat kematian larva selama 20 menit perendaman di setiap konsentrasi pada instar III dan IV. Pada waktu perendaman 40 menit, kematian larva terbanyak di konsentrasi 100mg dengan rata-rata kematian $60 \%$ pada instar III dan $56 \%$ pada instar IV. Rata-rata kematian larva pada perendaman selama 60 menit terbanyak di konsentrasi $100 \mathrm{mg}$ pada instar ke III dan ke IV yaitu sebesar $88 \%$. Semua larva mati di setiap konsentrasi pada instar III dan IV dalam waktu 24 jam perendaman. Hal ini menunjukkan 
semakin lama perendaman dengan konsentrasi bubuk abate yang tinggi, ditemukan rerata kematian larva juga lebih tinggi. Selain itu, hasil penelitian ini juga menunjukkan bahwa selain faktor lama perendaman dan konsentrasi larutan bubuk abate yang berpengaruh terhadap kematian larva Aedes aegypti, ternyata usia larva juga ikut berkontribusi, terbukti usia larva yang lebih muda jika terpapar $100 \mathrm{mg} / \mathrm{ml}$ larutan bubuk abate dengan lama perendaman 40 menit jumlah kematian larva lebih banyak terjadi pada instar III (60\%) dibandingkan instar IV. Demikian pula jika perendaman lebih lama (60 menit) dengan konsentrasi larutan bubuk abate $20 \mathrm{mg} / \mathrm{ml}$, jumlah kematian larva juga lebih banyak terjadi pada larva instar III (56\%) daripada instar IV (52\%).

Penggunanaan larutan bawang putih dalam membunuh larva nyamuk Aedes aegypti diperoleh

Tabel 1. Kematian Larva pada Larutan Bubuk Abate

\begin{tabular}{|c|c|c|c|c|c|c|c|c|c|c|}
\hline \multirow[t]{2}{*}{ Instar } & \multirow[t]{2}{*}{ Konsentrasi } & \multirow{2}{*}{$\begin{array}{c}\text { Jumlah } \\
\text { Larva } \\
\text { Uji }\end{array}$} & \multirow[t]{2}{*}{ Waktu } & \multirow{2}{*}{$\begin{array}{c}\text { Replikasi } \\
1\end{array}$} & \multirow{2}{*}{$\begin{array}{c}\text { Replikasi } \\
2\end{array}$} & \multirow{2}{*}{$\begin{array}{c}\text { Replikasi } \\
\mathbf{3}\end{array}$} & \multirow{2}{*}{$\begin{array}{c}\text { Replikasi } \\
4\end{array}$} & \multirow{2}{*}{$\begin{array}{c}\text { Total } \\
\text { Kematian } \\
\text { Larva }\end{array}$} & \multicolumn{2}{|c|}{$\begin{array}{l}\text { Rata- } \\
\text { Rata }\end{array}$} \\
\hline & & & & & & & & & $\mathrm{n}$ & $\%$ \\
\hline \multirow{5}{*}{ III } & $20 \mathrm{mg}$ & 25 & & 0 & 0 & 0 & 0 & 0 & 0 & 0 \\
\hline & $40 \mathrm{mg}$ & 25 & & 0 & 0 & 0 & 0 & 0 & 0 & 0 \\
\hline & $60 \mathrm{mg}$ & 25 & 20 & 0 & 0 & 0 & 0 & 0 & 0 & 0 \\
\hline & $80 \mathrm{mg}$ & 25 & menit & 0 & 0 & 0 & 0 & 0 & 0 & 0 \\
\hline & $100 \mathrm{mg}$ & 25 & & 0 & 0 & 0 & 0 & 0 & 0 & 0 \\
\hline \multirow{5}{*}{ IV } & $20 \mathrm{mg}$ & 25 & & 0 & 0 & 0 & 0 & 0 & 0 & 0 \\
\hline & $40 \mathrm{mg}$ & 25 & & 0 & 0 & 0 & 0 & 0 & 0 & 0 \\
\hline & $60 \mathrm{mg}$ & 25 & 20 & 0 & 0 & 0 & 0 & 0 & 0 & 0 \\
\hline & $80 \mathrm{mg}$ & 25 & menit & 0 & 0 & 0 & 0 & 0 & 0 & 0 \\
\hline & $100 \mathrm{mg}$ & 25 & & 0 & 0 & 0 & 0 & 0 & 0 & 0 \\
\hline \multirow{5}{*}{ III } & $20 \mathrm{mg}$ & 25 & & 7 & 8 & 7 & 7 & 29 & 7 & 28 \\
\hline & $40 \mathrm{mg}$ & 25 & & 8 & 8 & 9 & 8 & 33 & 8 & 32 \\
\hline & $60 \mathrm{mg}$ & 25 & 40 & 12 & 12 & 13 & 12 & 49 & 12 & 48 \\
\hline & $80 \mathrm{mg}$ & 25 & menit & 12 & 13 & 13 & 13 & 51 & 12 & 48 \\
\hline & $100 \mathrm{mg}$ & 25 & & 15 & 16 & 16 & 16 & 63 & 15 & 60 \\
\hline \multirow{5}{*}{ IV } & $20 \mathrm{mg}$ & 25 & & 7 & 7 & 7 & 7 & 28 & 7 & 28 \\
\hline & $40 \mathrm{mg}$ & 25 & & 8 & 8 & 9 & 8 & 33 & 8 & 32 \\
\hline & $60 \mathrm{mg}$ & 25 & 40 & 12 & 12 & 13 & 12 & 49 & 12 & 48 \\
\hline & $80 \mathrm{mg}$ & 25 & menit & 12 & 12 & 13 & 13 & 50 & 12 & 48 \\
\hline & $100 \mathrm{mg}$ & 25 & & 14 & 14 & 15 & 15 & 58 & 14 & 56 \\
\hline \multirow{5}{*}{ III } & $20 \mathrm{mg}$ & 25 & & 14 & 14 & 15 & 14 & 57 & 14 & 56 \\
\hline & $40 \mathrm{mg}$ & 25 & & 16 & 15 & 16 & 16 & 63 & 16 & 64 \\
\hline & $60 \mathrm{mg}$ & 25 & 60 & 18 & 17 & 18 & 18 & 71 & 18 & 72 \\
\hline & $80 \mathrm{mg}$ & 25 & menit & 20 & 20 & 21 & 21 & 82 & 20 & 80 \\
\hline & $100 \mathrm{mg}$ & 25 & & 22 & 22 & 21 & 22 & 87 & 22 & 88 \\
\hline \multirow{5}{*}{ IV } & $20 \mathrm{mg}$ & 25 & & 13 & 14 & 14 & 13 & 54 & 13 & 52 \\
\hline & $40 \mathrm{mg}$ & 25 & & 14 & 14 & 15 & 14 & 57 & 14 & 56 \\
\hline & $60 \mathrm{mg}$ & 25 & 60 & 17 & 16 & 16 & 17 & 66 & 17 & 68 \\
\hline & $80 \mathrm{mg}$ & 25 & menit & 19 & 20 & 20 & 20 & 79 & 19 & 76 \\
\hline & $100 \mathrm{mg}$ & 25 & & 22 & 21 & 21 & 22 & 86 & 22 & 88 \\
\hline \multirow{5}{*}{ III } & $20 \mathrm{mg}$ & 25 & & 25 & 25 & 25 & 25 & 100 & 25 & 100 \\
\hline & $40 \mathrm{mg}$ & 25 & & 25 & 25 & 25 & 25 & 100 & 25 & 100 \\
\hline & $60 \mathrm{mg}$ & 25 & 24 jam & 25 & 25 & 25 & 25 & 100 & 25 & 100 \\
\hline & $80 \mathrm{mg}$ & 25 & & 25 & 25 & 25 & 25 & 100 & 25 & 100 \\
\hline & $100 \mathrm{mg}$ & 25 & & 25 & 25 & 25 & 25 & 100 & 25 & 100 \\
\hline \multirow{5}{*}{ IV } & $20 \mathrm{mg}$ & 25 & & 25 & 25 & 25 & 25 & 100 & 25 & 100 \\
\hline & $40 \mathrm{mg}$ & 25 & & 25 & 25 & 25 & 25 & 100 & 25 & 100 \\
\hline & $60 \mathrm{mg}$ & 25 & 24 jam & 25 & 25 & 25 & 25 & 100 & 25 & 100 \\
\hline & $80 \mathrm{mg}$ & 25 & & 25 & 25 & 25 & 25 & 100 & 25 & 100 \\
\hline & $100 \mathrm{mg}$ & 25 & & 25 & 25 & 25 & 25 & 100 & 25 & 100 \\
\hline
\end{tabular}


Tabel 2. Kematian Larva pada Larutan Bawang Putih

\begin{tabular}{|c|c|c|c|c|c|c|c|c|c|c|}
\hline \multirow{2}{*}{ Instar } & \multirow{2}{*}{ Konsentrasi } & \multirow{2}{*}{$\begin{array}{c}\text { Jumlah } \\
\text { Larva } \\
\text { Uji } \\
\end{array}$} & \multirow{2}{*}{ Waktu } & \multirow{2}{*}{$\begin{array}{l}\text { Repli- } \\
\text { kasi } 1\end{array}$} & \multirow{2}{*}{$\begin{array}{l}\text { Repli- } \\
\text { kasi } 2\end{array}$} & \multirow{2}{*}{$\begin{array}{l}\text { Repli- } \\
\text { kasi } 3\end{array}$} & \multirow{2}{*}{$\begin{array}{l}\text { Repli- } \\
\text { kasi } 4\end{array}$} & \multirow{2}{*}{$\begin{array}{c}\text { Total } \\
\text { Kematian } \\
\text { Larva } \\
\end{array}$} & \multicolumn{2}{|c|}{ Rata-Rata } \\
\hline & & & & & & & & & $\mathbf{n}$ & $\%$ \\
\hline \multirow{5}{*}{ III } & $20 \mathrm{mg}$ & 25 & & 0 & 0 & 0 & 0 & 0 & 0 & 0 \\
\hline & $40 \mathrm{mg}$ & 25 & & 0 & 0 & 0 & 0 & 0 & 0 & 0 \\
\hline & $60 \mathrm{mg}$ & 25 & 20 & 0 & 0 & 0 & 0 & 0 & 0 & 0 \\
\hline & $80 \mathrm{mg}$ & 25 & menit & 0 & 0 & 0 & 0 & 0 & 0 & 0 \\
\hline & $100 \mathrm{mg}$ & 25 & & 0 & 0 & 0 & 0 & 0 & 0 & 0 \\
\hline \multirow{5}{*}{ IV } & $20 \mathrm{mg}$ & 25 & & 0 & 0 & 0 & 0 & 0 & 0 & 0 \\
\hline & $40 \mathrm{mg}$ & 25 & & 0 & 0 & 0 & 0 & 0 & 0 & 0 \\
\hline & $60 \mathrm{mg}$ & 25 & 20 & 0 & 0 & 0 & 0 & 0 & 0 & 0 \\
\hline & $80 \mathrm{mg}$ & 25 & menit & 0 & 0 & 0 & 0 & 0 & 0 & 0 \\
\hline & $100 \mathrm{mg}$ & 25 & & 0 & 0 & 0 & 0 & 0 & 0 & 0 \\
\hline \multirow{5}{*}{ III } & $20 \mathrm{mg}$ & 25 & & 0 & 0 & 0 & 0 & 0 & 0 & 0 \\
\hline & $40 \mathrm{mg}$ & 25 & & 0 & 0 & 0 & 0 & 0 & 0 & 0 \\
\hline & $60 \mathrm{mg}$ & 25 & 40 & 0 & 0 & 0 & 0 & 0 & 0 & 0 \\
\hline & $80 \mathrm{mg}$ & 25 & menit & 0 & 0 & 0 & 0 & 0 & 0 & 0 \\
\hline & $100 \mathrm{mg}$ & 25 & & 0 & 0 & 0 & 0 & 0 & 0 & 0 \\
\hline \multirow{5}{*}{ IV } & $20 \mathrm{mg}$ & 25 & & 0 & 0 & 0 & 0 & 0 & 0 & 0 \\
\hline & $40 \mathrm{mg}$ & 25 & & 0 & 0 & 0 & 0 & 0 & 0 & 0 \\
\hline & $60 \mathrm{mg}$ & 25 & 40 & 0 & 0 & 0 & 0 & 0 & 0 & 0 \\
\hline & $80 \mathrm{mg}$ & 25 & menit & 0 & 0 & 0 & 0 & 0 & 0 & 0 \\
\hline & $100 \mathrm{mg}$ & 25 & & 0 & 0 & 0 & 0 & 0 & 0 & 0 \\
\hline \multirow{5}{*}{ III } & $20 \mathrm{mg}$ & 25 & & 0 & 0 & 0 & 0 & 0 & 0 & 0 \\
\hline & $40 \mathrm{mg}$ & 25 & & 0 & 0 & 0 & 0 & 0 & 0 & 0 \\
\hline & $60 \mathrm{mg}$ & 25 & 60 & 0 & 0 & 0 & 0 & 0 & 0 & 0 \\
\hline & $80 \mathrm{mg}$ & 25 & menit & 0 & 0 & 0 & 0 & 0 & 0 & 0 \\
\hline & $100 \mathrm{mg}$ & 25 & & 0 & 0 & 0 & 0 & 0 & 0 & 0 \\
\hline \multirow{5}{*}{ IV } & $20 \mathrm{mg}$ & 25 & & 0 & 0 & 0 & 0 & 0 & 0 & 0 \\
\hline & $40 \mathrm{mg}$ & 25 & & 0 & 0 & 0 & 0 & 0 & 0 & 0 \\
\hline & $60 \mathrm{mg}$ & 25 & 60 & 0 & 0 & 0 & 0 & 0 & 0 & 0 \\
\hline & $80 \mathrm{mg}$ & 25 & menit & 0 & 0 & 0 & 0 & 0 & 0 & 0 \\
\hline & $100 \mathrm{mg}$ & 25 & & 0 & 0 & 0 & 0 & 0 & 0 & 0 \\
\hline \multirow{5}{*}{ III } & $20 \mathrm{mg}$ & 25 & & 20 & 20 & 20 & 21 & 81 & 20,25 & 81 \\
\hline & $40 \mathrm{mg}$ & 25 & & 20 & 20 & 21 & 21 & 82 & 20,5 & 82 \\
\hline & $60 \mathrm{mg}$ & 25 & $24 \mathrm{jam}$ & 24 & 24 & 24 & 23 & 95 & 23,75 & 95 \\
\hline & $80 \mathrm{mg}$ & 25 & & 24 & 24 & 24 & 24 & 96 & 24 & 96 \\
\hline & $100 \mathrm{mg}$ & 25 & & 25 & 25 & 25 & 25 & 100 & 25 & 100 \\
\hline \multirow{5}{*}{ IV } & $20 \mathrm{mg}$ & 25 & & 20 & 19 & 20 & 20 & 79 & 19,75 & 79 \\
\hline & $40 \mathrm{mg}$ & 25 & & 20 & 19 & 19 & 20 & 78 & 19,5 & 78 \\
\hline & $60 \mathrm{mg}$ & 25 & $24 \mathrm{jam}$ & 24 & 24 & 23 & 24 & 95 & 23,75 & 95 \\
\hline & $80 \mathrm{mg}$ & 25 & & 24 & 23 & 24 & 24 & 95 & 23,75 & 95 \\
\hline & $100 \mathrm{mg}$ & 25 & & 25 & 25 & 25 & 25 & 100 & 25 & 100 \\
\hline
\end{tabular}

bahwa tidak ada kematian larva di menit ke 20, 40, dan 60 perendaman larva di setiap konsentrasi pada instar ke III dan ke IV. Namun, terdapat kematian larva pada 24 jam perendaman disetiap konsentrasi larutan, dan rata-rata kematian larva terbanyak pada konsentrasi $100 \mathrm{mg}$ pada kedua instar yaitu sebesar 100. Hasil penelitian juga menunjukkan bahwa semakin tinggi konsentrasi larutan bawang putih dengan lama perendaman 24 jam, semakin tinggi pula jumlah kematian jumlah larva nyamuk Aedes aegypti (Tabel 2).

Jika dibandingkan efektifitas kematian larva antara penggunaan bubuk abate dan larutan bawang putih, diperoleh hasil bahwa tidak terdapat perbedaan yang signifikan antara intervensi bubuk abate dan larutan bawang putih pada semua konsentrasi dalam waktu 20 menit perendaman nyamuk Aedes aegypti. Sebaliknya terdapat per- 
Tabel 3a. Perbandingan Efektivitas Bubuk Abate dan Larutan Bawang Putih

\begin{tabular}{|c|c|c|c|c|c|}
\hline Waktu & Konsentrasi & Intervensi & $\mathrm{n}$ & Mean Rank & p-value \\
\hline & $20 \mathrm{mg}$ & Abate & 8 & 8,50 & 1,000 \\
\hline & & Bawang Putih & 8 & 8,50 & \\
\hline & & Total & 16 & & \\
\hline & $40 \mathrm{mg}$ & Abate & 8 & 8,50 & 1,000 \\
\hline & & Bawang Putih & 8 & 8,50 & \\
\hline & & Total & 16 & & \\
\hline \multirow[t]{15}{*}{20 menit } & $60 \mathrm{mg}$ & Abate & 8 & 8,50 & 1,000 \\
\hline & & Bawang Putih & 8 & 8,50 & \\
\hline & & Total & 16 & & \\
\hline & $80 \mathrm{mg}$ & Abate & 8 & 8,50 & 1,000 \\
\hline & & Bawang Putih & 8 & 8,50 & \\
\hline & & Total & 16 & & \\
\hline & $100 \mathrm{mg}$ & Abate & 8 & 8,50 & 1,000 \\
\hline & & Bawang Putih & 8 & 8,50 & \\
\hline & & Total & 16 & & \\
\hline & $20 \mathrm{mg}$ & Abate & 8 & 12,50 & 0,000 \\
\hline & & Bawang Putih & 8 & 4,50 & \\
\hline & & Total & 16 & & \\
\hline & $40 \mathrm{mg}$ & Abate & 8 & 12,50 & 0,000 \\
\hline & & Bawang Putih & 8 & 4,50 & \\
\hline & & Total & 16 & & \\
\hline \multirow[t]{15}{*}{40 menit } & $60 \mathrm{mg}$ & Abate & 8 & 12,50 & 0,000 \\
\hline & & Bawang Putih & 8 & 4,50 & \\
\hline & & Total & 16 & & \\
\hline & $80 \mathrm{mg}$ & Abate & 8 & 12,50 & 0,000 \\
\hline & & Bawang Putih & 8 & 4,50 & \\
\hline & & Total & 16 & & \\
\hline & $100 \mathrm{mg}$ & Abate & 8 & 12,50 & 0,000 \\
\hline & & Bawang Putih & 8 & 4,50 & \\
\hline & & Total & 16 & & \\
\hline & & Abate & 8 & 12,50 & 0,000 \\
\hline & $20 \mathrm{mg}$ & Bawang Putih & 8 & 4,50 & \\
\hline & & Total & 16 & & \\
\hline & & Abate & 8 & 12,50 & 0,000 \\
\hline & $40 \mathrm{mg}$ & Bawang Putih & 8 & 4,50 & \\
\hline & & Total & 16 & & \\
\hline
\end{tabular}

bedaan yang signifikan intervensi bubuk abate dan bawang putih di semua konsentrasi larutan pada menit ke 40 dan 60 perendaman. Demikian pula dengan perendaman 24 jam pada konsentrasi 20 $\mathrm{mg}, 40 \mathrm{mg}, 60 \mathrm{mg}$ dan $80 \mathrm{mg}$ juga ditemukan perbedaan kematian larva nyamuk Aedes aegpy$t i$ secara bermakna. Namun, tidak ada perbedaan yang signifikan antara intervensi bubuk abate dan larutan bawang putih pada konsentrasi larutan 100 $\mathrm{mg} / \mathrm{ml}$ dalam waktu 24 jam perendaman (Tabel 3).

\section{PEMBAHASAN}

Hasil studi ini menunjukkan bahwa kema- tian larva Aedes aegypti pada penggunaan larutan bubuk abate dan larutan bawang putih dengan lama perendaman 20 menit dari berbagai level konsentrasi ternyata mempelihatkan hasil yang sama yakni belum ditemukan larva yang mati dalam kondisi tersebut. Namun, setelah perendaman 40 menit dan 60 menit di semua level konsentrasi kedua jenis larutan mulai memperlihatkan hasil yang berbeda secara signifikan $(p=0,000)$ diantara kedua jenis perlakuan. Larutan bubuk abate lebih cepat memberikan reaksi (responsiveness) dalam membunuh larva Aedes aegypti instar III dan IV yakni pada perendaman 40 menit larutan 
Tabel 3b. Perbandingan Efektivitas Bubuk Abate dan Larutan Bawang Putih

\begin{tabular}{|c|c|c|c|c|c|}
\hline Waktu & Konsentrasi & Intervensi & $\mathrm{n}$ & Mean Rank & p-value \\
\hline \multirow[t]{15}{*}{60 menit } & $60 \mathrm{mg}$ & Abate & 8 & 12,50 & 0,000 \\
\hline & & Bawang Putih & 8 & 4,50 & \\
\hline & & Total & 16 & & \\
\hline & $80 \mathrm{mg}$ & Abate & 8 & 12,50 & 0,000 \\
\hline & & Bawang Putih & 8 & 4,50 & \\
\hline & & Total & 16 & & \\
\hline & $100 \mathrm{mg}$ & Abate & 8 & 12,50 & 0,000 \\
\hline & & Bawang Putih & 8 & 4,50 & \\
\hline & & Total & 16 & & \\
\hline & $20 \mathrm{mg}$ & Abate & 8 & 12,50 & 0,000 \\
\hline & & Bawang Putih & 8 & 4,50 & \\
\hline & & Total & 16 & & \\
\hline & $40 \mathrm{mg}$ & Abate & 8 & 12,50 & 0,000 \\
\hline & & Bawang Putih & 8 & 4,50 & \\
\hline & & Total & 16 & & \\
\hline \multirow[t]{9}{*}{$24 \mathrm{Jam}$} & $60 \mathrm{mg}$ & Abate & 8 & 12,50 & 0,000 \\
\hline & & Bawang Putih & 8 & 4,50 & \\
\hline & & Total & 16 & & \\
\hline & $80 \mathrm{mg}$ & Abate & 8 & 12,50 & 0,000 \\
\hline & & Bawang Putih & 8 & 4,50 & \\
\hline & & Total & 16 & & \\
\hline & $100 \mathrm{mg}$ & Abate & 8 & 8,50 & 1,000 \\
\hline & & Bawang Putih & 8 & 8,50 & \\
\hline & & Total & 16 & & \\
\hline
\end{tabular}

bubuk abate telah ditemukan larva Aedes aegypti yang mati. Sebaliknya untuk larutan bawang putih belum ada sama sekali larva yang mati pada perendaman 40 menit di berbagai level konsentrasi. Hal ini menunjukkan bahwa pengendalian secara kimiawi bekerja lebih efektif dan hasilnya cepat terlihat di bandingkan pengendalian secara biologis, dengan waktu keterpaparan yang singkat. Bubuk abate merupakan golongan pestisida yang bekerja menghambat enzim cholinesterase yang menyebabkan gangguan aktivitas syarat akibat tertimbunya acetylcholine pada ujung syaraf. Pada ujung saraf serangga akan dihasilkan acetycholine apabila mendapatkan stimulasi atau rangsangan, yang berfungsi sebagai mediator atau perantara, antara saraf dan otot daging sehingga memungkinkan impuls listrik yang merangsang otot daging untuk berkontraksi acetycholine tidak segera dihancurkan maka otot akan tetap berkontraksi dalam waktu lama sehingga akan terjadi kekejangan atau konvulsi. Abate sebagai golongan pestisida organophosphate, menyebabkan enzim cholinesterase akan diikat atau dihancurkan sehingga terjadi kekejangan otot secara terus menerus, dan serangga akhirnya akan mati. ${ }^{9}$

Beberapa hasil studi sebelumnya menunjukkan bahwa bubuk abate mempunyai kapasitas larvacida yang lebih tinggi dibandingkan senyawa dari botani seperti hasil studi Martha yang menemukan rata-rata kematian larva lebih tinggi (70.000) dibandingkan dengan biji (20.000) dan berbeda secara bermakna $(p=0,002) .{ }^{9}$ Demikian pula dengan hasil studi Prastha KAI dan Santjaka A, menghasilkan rata-rata kematian larva Aedes aegypti yang tertinggi pada larvasida abate dosis $0,1 \mathrm{gr} / 1$ yaitu 25 ekor (100\%), sedangkan ekstrak daun sirsak dosis $1 \mathrm{gr} / 1$ yaitu 23 ekor $(93,3 \%)$ dan ekstrak daun sirih dosis $1 \mathrm{gr} / 1$ yaitu 18 ekor $(70,6 \%) .^{10}$

Hasil penelitian ini juga menunjukkan bahwa setiap konsentrasi larutan bawang putih jumlah kematian larva juga berbeda-beda, hal ini mengindikasikan adanya perbedaan sensitivitas setiap larva terhadap konsentrasi larutan, yakni semakin tinggi konsentrasi larutan maka tingkat kekentalan larutan juga semakin tinggi, sehingga menjadi 
penghalang bagi larva Aedes aegypti untuk mengambil $\mathrm{O}_{2}$ dari permukaan air, sehingga $\mathrm{O}_{2}$ berkurang untuk mendukung pertumbuhannnya, dengan demikian angka kematian yang tinggi mungkin dikaitkan dengan kekurangan oksigen terlarut dalam air. Selain konsentrasi dan lama perendaman yang berpengaruh terhadap kematian larva Aedes aegypti, pada kelompok larva yang mendapatkan larutan bawang putih ditemukan adanya kecenderungan bahwa semakin muda umur larva ternyata tingkat kematian larva lebih tinggi seiring dengan peningkatan konsentrasi larutan bawang putih pada perendaman 24 jam. Hal ini menunjukkan bahwa stadium larva sangat mempengaruhi reaksi terhadap zat toksik.

Hasil studi ini juga memperlihatkan bahwa semakin lama perendaman dengan konsentrasi larutan bubuk abate dan larutan bawang putih yang tinggi memberikan kemampuan larvasid yang sangat tinggi, yakni 100\% larva Aedes aegypti mati pada perendaman 24 jam dan konsentrasi larutan sebanyak $100 \mathrm{mg} / \mathrm{ml}$ untuk kedua jenis intervensi. Tidak ditemukan perbedaan yang signfikan $(\mathrm{p}$ $=1.000$ ) kematian larva Aedes aegypti pada kedua jenis larutan (bubuk abate dan bawang putih) dengan konsentrasi $100 \mathrm{mg} / \mathrm{ml}$ selama 24 jam perendaman.

Penetrasi abate ke dalam larva berlangsung cepat yaitu dalam waktu 24 jam setelah perlakuan lebih dari 99\% temefos dalam medium diabsorpsi ke tubuh larva. Setelah diabsorpsi, temefos diubah menjadi produk metabolism, dan sebagian dari produk metabolik diekskresikan ke dalam air. ${ }^{12}$ Mekanisme larvasida dari bawang putih dapat disebabkan oleh zat aktif (Allicin, diallyl disulfide, phenoclic acid, saponin, sapogenin, alkaloid, tannin dan Flavonoid) yang terkandung di dalamnya dan kontak langsung dengan larva, sehingga semakin tinggi konsentrasi bawang putih maka kandungan zat aktif juga akan semakin tinggi, yang dapat memengaruhi kematian larva pada berbagai konsentrasi. ${ }^{13}$ Hasil studi Sumampouw, dkk juga membuktikan bahwa jumlah kematian larva berbanding lurus dengan kematian larva Aedes spp. ${ }^{13}$ Medona dan Nirmala menemukan bahwa walaupun konsentrasi sangat rendah bawang putih tetap memiliki efek larvacida, ${ }^{5}$ demikian pula dengan hasil penelitian Sulistyoningsih ddk, ${ }^{14}$ Susheela, ${ }^{15}$ dan Muturi $\mathrm{dkk}^{8}$ menunjukkan bahwa Allyl disul- fide yang terdapat pada bawang putih menunjukkan aktivitas ovicidal dan larvicidal yang kuat. Menurut WHO, konsentrasi larvasida dianggap efektif apabila dapat menyebabkan kematian larva uji antara $10-95 \%$ dalam waktu 24 jam atau 48 jam. ${ }^{16}$

Berdasarkan hasil penelusuran literatur tidak ada satu pun hasil penelitian yang membandingkan penggunaan bubuk abate dan bawang putih terhadap kematian larva Aedes aegypti, sehingga peneliti menggunakan hasil studi pembanding yang menggunakan bahan botani lainnya sebagai larvasida, diantaranya hasil studi Nadila, dkk yang menemukan kematian 100\% larva Aedes aegypti sejak paparan 24 jam pada kelompok kontrol positif (bubuk abate), dan tidak ditemukan perbedaan yang signifikan $(p=0,371)$ antara ekstrak daun etanol binjai dengan abate (temephos) $100 \mathrm{mg} / \mathrm{L}$ terhadap kematian larva Aedes aegypti. ${ }^{17}$

\section{KESIMPULAN DAN SARAN}

Jumlah kematian larva lebih cepat terjadi pada penggunaan bubuk abate (menit ke-40) dibandingkan penggunaan larutan bawang putih. Tidak ada perbedaan jumlah kematian larva dalam waktu 24 jam pada konsentrasi $100 \mathrm{mg} / 100 \mathrm{ml}$ antara penggunaan larutan bawang putih dan bubuk abate $(\mathrm{p}=1.000)$. Oleh karena itu, larutan bawang putih dengan konsentrasi $100 \mathrm{mg} / 100$ $\mathrm{ml}$ dapat digunakan sebagai larvasida alternatif untuk membunuh larva nyamuk Aedes aegypti secara alami. Diperlukan studi lebih lanjut untuk mengkaji bagaimana menghilangkan bau, rasa dan warna dari bawang putih pada air yang diberi larutan bawang putih agar kriteria larvasid yang baik dari bawang putih terpenuhi, sehingga hasil yang diperoleh lebih optimal dalam mengendalikan larva Aedes aegypti.

\section{DAFTAR PUSTAKA}

1. Goyal M, Shinde L, Bayas R. Study of Chemical Composition and Larvicidal Efficacy of Secondary Metabolites from Aromatic Phytoextracts Against Dengue Vector: Aedes Aegypti (Linn) (Diptera: Culicidae). International Journal of Mosquito Research. 2019;6(1):26-33.

2. Sanyaolu A, Okorie C, Badaru O, Adetona K, et al. Global Epidemiology of Dengue He- 
morrhagic Fever: An Update. Journal of Human Virolology \& Retrovirology. 2017;5(6):1-7.

3. Kemenkes RI. Situasi Penyakit Demam Berdarah di Indonesia tahun 2017. Infodatin: Pusat Data dan Informasi Kementerian Kesehatan RI. Jakarta: Kementerian Kesehatan RI; 2018.

4. Shukla D, Wijayapala S \& Vankar PS. Effective Mosquito Repellent from Plant Based Formulation. International Journal Mosquito Research. 2018;5(1):19-24.

5. Medona MR, Nirmala T. Larvicidal Activity of Five Different Plant Extracts Against Aedes Aegypti (Linn). International Journal of Research \& Review. 2016;3(1):65-72.

6. Rochmat A, Bahiyah Z \& Adiati F. Pengembangan Biolarvasida Jentik Nyamuk Aedes Aegypti Berbahan Aktif Ekstrak Beluntas (Pluchea Indica Less.). Reaktor Chemical Engineering Journal. 2017;16(3):103-108.

7. Baker, B. P. \& Grant JA. Garlic and Garlic Oil Profile. New York State: IPM Progr; 2018.

8. Muturi, EJ, Ramirez, JL, Zilkowski B, Flor-Weile LB. \& Rooney AP. Ovicidal and Larvicidal Effects of Garlic and Asafoetida Essential Oils Against West Nile Virus Vectors. Journal Insect Science. 2018;18(2):1-6.

9. Martha E. Analisis Efektifitas Penghambat Pertumbuhan Larva Aedes Aegypti dengan Menggunakan Carcia Papaya Linnaeus. Jurnal Kreatif Industri. 2019;3(1):21-26.

10. Prastha K, Santjaka A. Efektivitas Larvasida Antara Abate, Ekstrak Daun Sirsak (Annona Muricata Linn) dan Ekstrak Daun Sirih (Piper
Betle Linn) terhadap Kematian Larva Aedes Aegypti Instar 3 Tahun 2015. Buletin Kesehatan Lingkungan Masyarakat. 34(3):175-179.

11. Yulidar HZ. Kerusakan Larva Aedes Aegypti (Linn) Setelah Terpapar Temefos pada Fase Larva Instar 3 (L). Jurnal BUSKI. 2014;5(1):23-28.

12. Sasmiliati U, Pratiwi AD, Saktiawan LOA. Efektivitas Larutan Bawang Putih (Allium Sativum Linn) sebagai Larvasida terhadap Kematian Larva Aedes Agypti di Kota Kendari tahun 2016. Jurnal Ilmiah Mahasiwa Kesehatan Masyarakat. 2017;2(6):1-7.

13. Sumampouw SPM, Pijoh VD, Wahongan GJP. Pengaruh Larutan Bawang Putih (Allium Sativum) pada Larva Aedes spp di Kecamatan Malalayang Kota Manado. Jurnal e-Biomedik. 2014;2(2):436-441.

14. Sulistyoningsih D, Santoso B, Sumanto D. Efektivitas larutan bawang putih dalam membunuh larva. Jurnal Kesehatan. 2009;2(2):3844.

15. Susheela $\mathrm{P}, \mathrm{Radha} \mathrm{R}, \&$ Padmapriyanga $\mathrm{S}$. Evaluation of Larvicidal Action of Natural Extracts on Mosquito Larvae of Aedes Aegypti (Diptera: Culicidae). International Journal of Mosquito Research. 2016;3(6):26-30.

16. WHO. Monitoring and Managing Insecticide Resistance in Aedes Aegypti Mosquito Population Interim Guidance for Entomologis. Geneva; 2016.

17. Nadila I, Istiana, Wydiamala E. Aktivitas Larvasida Ekstrak Etanol Daun Binjai (Mangifera Caesia) terhadap Larva Aedes Aegypti. Berkala Kedokteran. 2017;13(1):61-68. 